\title{
HIGHLY REVERSIBLE ELECTROCHEMICAL INSERTION OF LITHIUM, ACCOMPANIED WITH A MARKED COLOR CHANGE, OCCURING IN MICROCRYSTALLINE LITHIUM NICKEL OXIDE FILMS
}

\author{
G. CAMPET, J. PORTIER \\ Laboratoire de Chimie du Solide du CNRS, 351 cours de la Libération - 33405 Talence cédex \\ (France) \\ B. MOREL, D. FERRY, J.M. CHABAGNO, L. BENOTMANE, \\ M. BOURREL \\ Groupe de Recherches de Lacq du Groupe Elf-Aquitaine B.P. 34 - 64170 Artix (France) \\ (Received July 30, 1991; in final form August 22, 1991)
}

\begin{abstract}
Thin films of lithium-nickel oxide, whose texture consists of microcrystallites with an average grain size of $50 \AA$, permit highly reversible electrochemical insertion of lithium ions in $\mathrm{Li}^{+}$conducting electrolytes. Therefore, the corresponding materials would be of great interest for energy storage applications. In addition, the lithium insertion/extraction reactions in the nickel-based layers are accompanied with a marked color change, making these films of interest for the development of electrochromic displays for the control of light transmission in windows ("smart windows").
\end{abstract}

\section{INTRODUCTION}

Thin film-electrochromic (EC) materials (ECM) and displays (ECD) present a basis for light modulators and other electro-optic devices. The ECD can be presumed as a system $E_{1} / M_{1} / I / M_{2} / E_{2}$, containing an $E C M\left(M_{1}\right)$, an ion conducting material (I), and the so-called counter-electrode $\left(\mathrm{M}_{2}\right)$ between two electronic conductors $\left(E_{1}\right.$ and $E_{2}$ ) serving as ohmic contacts. If $M_{1}$ is an ECM which colors during the cathodic process when electrons and small cations $\left(\mathrm{H}^{+}, \mathrm{Li}^{+}, \mathrm{Na}^{+}\right.$, and others $)$are being injected, then $\mathrm{M}_{2}$ must be reversible to ions involved in the $\mathrm{EC}$ reaction. However, the most promising ECD are those containing two ECM, i.e. coloring cathodically $\left(\mathrm{M}_{1}\right)$ and coloring anodically $\left(\mathrm{M}_{2}\right)$ : that leads indeed to an increase of the optical efficiency of the ECD. The most important problem in the development of such ECD is the compatibility of $\mathrm{M}_{1}$ and $\mathrm{M}_{2}$ with the solid electrolyte (I). In this prospect, $M_{1}$ and $M_{2}$ should be selected among transition metal oxides, such as:

(i) $\mathrm{WO}_{3}, \mathrm{MoO}_{3}, \mathrm{~V}_{2} \mathrm{O}_{5}, \mathrm{TiO}_{2}$; they color cathodically and, therefore, constitute in thin film the $\mathrm{M}_{1}$ electrodes of the ECD (1-3).

(ii) $\mathrm{IrO}_{\mathrm{x}} \mathrm{H}_{y}, \mathrm{NiO}_{\mathrm{x}} \mathrm{H}_{\mathrm{y}}$; they behave, in thin films, as $\mathrm{M}_{2}$ electrodes as they color 
anodically, i.e. upon removal of cations (4-6). Therefore they behave optically in a complementary fashion to $\mathbf{M}_{1}$.

Concerning class (ii) oxides, reversible charge insertion processes have been mainly observed in aqueous electrolytes (4-6). However, long term electochemical stability, at elevated temperatures, of ECD is likely to occur when $\mathrm{Li}^{+}$rather than $\mathrm{H}^{+}$is used as the mobile species (7-10). We have recently reported on a new strategy,${ }^{*}$ and related experiments, that have enabled us of bringing to light a new family of $\mathrm{ECM}_{2}$ electrodes operating with $\mathrm{Li}^{+}$ions (designated below as $\mathrm{ECM}_{2}$ $\left.\left(\mathrm{Li}^{+}\right)\right)(11,12)$.

This paper presents the results of some of our investigations, within the framework of this strategy, on a new $\mathrm{ECM}_{2}\left(\mathrm{Li}^{+}\right)$of composition:

$$
\mathrm{Li}_{2-x}^{+} \mathrm{Ni}_{1-x}^{\mathrm{II}} \mathrm{Ni}_{\mathrm{x}}^{\mathrm{III}} \mathrm{O}_{2}
$$

For sake of clarity we will mainly focus on the EC properties of the films (results concerning the determinations of film structure and texture, chemical and physical analysis, transport properties, etc., will be reported elsewhere (13)). In this prospect, their similar optical properties with "X-ray amorphous" $\mathrm{WO}_{3}$ films (13) will also be evaluated. Finally, the EC properties of complete polymeric-solid-state $\mathrm{ECD}$, using $\mathrm{WO} 3$ as $\mathrm{ECM}_{1}$, and nickel or chromium-based $\mathrm{ECM}_{2}$ will be investigated.

\section{EXPERIMENTAL}

Float-glass substrates of $50 \times 50 \mathrm{~mm}$ size, coated with a thin layer of transparent, electronic-conductive material ( $\mathrm{E}_{1} \mathrm{E}_{2} \quad$ ITO) have been used.

The nickel-based $\mathrm{ECM}_{2}$ electrodes are prepared by RF sputtering at room temperature of home made targets of $100 \mathrm{~mm}$ diameter (table I). It is followed by an electrochemical treatment performed in a dry box; the procedure makes use of a two-electrode cell configuration, namely, the Ni-based films and a lithium counterreference electrode. Both electrodes are immersed in a $1 \mathrm{MLiClO}_{4}$ propylene carbonate electrolyte. The film is then polarized at $1.5 \mathrm{~V}$ for $20 \mathrm{mn}$ in order to get the final $\mathrm{X}$-ray amorphous material $\mathrm{Li}_{2} \mathrm{NiO}_{2}$.

As for the $\mathrm{WO}_{3}$ electrodes ( $1100 \AA$ thick), they were prepared by DC sputtering of a metallic $\mathrm{W}$ target (10).

The EC properties of each separate ECM were studied in a dry box using the above mentioned electrochemical cell.

A polyurethane-based polymer containing $\mathrm{LiClO}_{4}(10)$ was used as the electrolyte in a complete ECD. The basic structure of the corresponding laminated-lithium-

\footnotetext{
* It takes into consideration polycrystalline lithiated semiconducting films: the reversible-electrochemical insertion process of lithium would be all the more efficient as the crystallite size is reduced. It would be highly efficient for X-ray amorphous lithiated films whose texture consists of microcrystallites of less than $50 \AA$ size.
} 
TABLE I

Experimental conditions for the reactive RF sputtering of lithium and nickel-based films.

\begin{tabular}{ll}
\hline Target & $\mathrm{LiNiO}_{2}$ \\
Initial pressure & $10^{-5} \mathrm{mbar}$ \\
Atmosphere & $\mathrm{Ar}(80 \%)-\mathrm{O}_{2}(20 \%)$ \\
Pressure & $10^{-2} \mathrm{mbar}$ \\
Sputtering time & $80 \mathrm{mn}$ \\
Film thickness & $1100 \AA$ \\
\hline
\end{tabular}

based ECD is:

Float glass ITO $\mathrm{Li}_{\mathrm{x}} \mathrm{Wo}_{3} \quad \mathrm{SPE} \quad \mathrm{Li}_{2-\mathrm{x}} \mathrm{NiO}_{2} \quad$ ITO Float glass

$\mathrm{Li}+$

With SPE symbolizing the Solid Polymer Electrolyte.

The cycling and optical tests were obtained with standard electrochemical and optical equipment (12).

\section{ELECTROCHEMICAL-CHROMIC PROPERTIES OF SEPARATE} EC LAYERS: study of " $\mathrm{Li} / \mathrm{LiClO}_{4}-\mathrm{pc} / \mathrm{Li}_{2-x}^{+} \mathrm{Ni}_{1-x}^{\mathrm{II}} \mathrm{Ni}_{\mathrm{x}}^{\mathrm{III}} \mathrm{O}_{2}^{2-} / \mathrm{ITO} /$ glass," " $\mathrm{Li} / \mathrm{LiClO}_{4}-\mathrm{pc} / \mathrm{Li}_{\mathrm{x}}^{+} \mathrm{W}_{\mathrm{x}}^{5+} \mathrm{W}_{1-\mathrm{x}}^{6+} \mathrm{O}_{3}^{-2} / \mathrm{ITO} /$ glass," cells

The electrochemi-chromic testing must be processed within an appropriate voltage range to avoid electrolyte oxidation on the one hand and (eventual) ITO reduction on the other hand.

In this prospect, the electrochemical stability of the $\mathrm{LiClO}_{3}-\mathrm{PC}$, of the $\mathrm{LiClO}_{4}$ based polurethane electrolyte, and of ITO was first established by cyclic voltammetry using a bare ITO-coated glass. The resulting voltammograms reveal an electrochemical-stability range confined between $1.5 \mathrm{~V}$ and $3.8 \mathrm{~V}$ vs $\mathrm{Li}$ (fig. 1).

Corresponding coloring and bleaching cycles of the ECM, performed within the electrochemical stability range fixed above and using the above mentioned cell configuration are reported in fig. 2 (a-b).

For all films the $\mathrm{Li}^{+}$electrochemical (des)insertion was readily reversible. The charge transferred was as high as $2.5 \times 10^{3} \mathrm{C} / \mathrm{cm}^{3}$ even after $10^{4}$ cycles. The knowledge of the range of film specific weigh of $3-4 \mathrm{~g} / \mathrm{cm}^{3}(13)$ would give, for all samples, a modulation of the lithium content of about $0.4-0.5$.

We will present evidence elsewhere, from textural characterizations (TEM, SEM, RBS analysis) and by using pulse-based electrical techniques, that the kinetics of the electrochemical process is mainly controlled by diffusion of $\mathrm{Li}^{-}$ions through the films on the crystallite surface (14). 


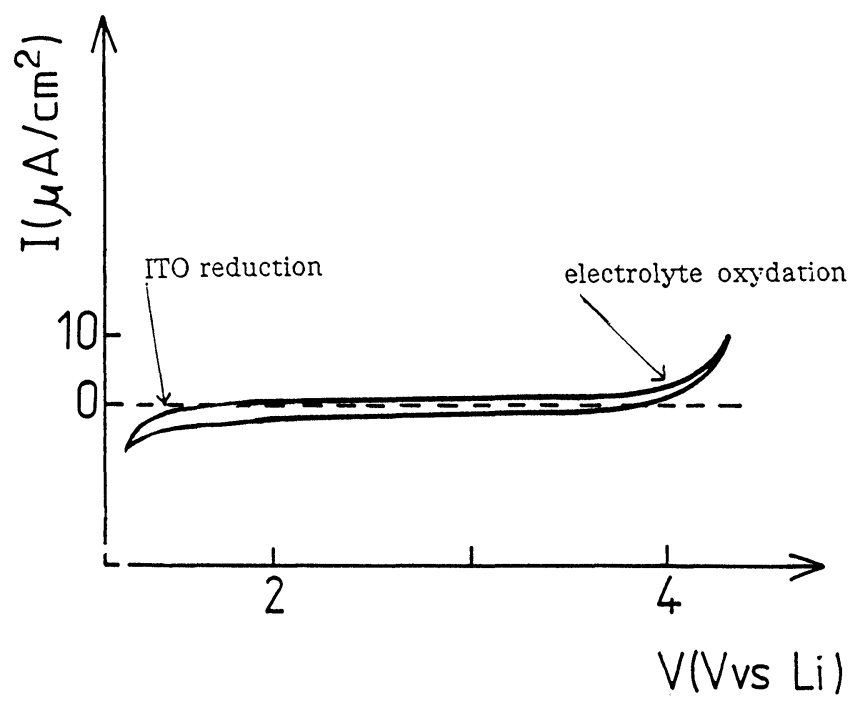

FIGURE 1 Electrochemical stability range of the system: $\mathrm{LiClO}_{+}-\mathrm{PC}$ (or $\mathrm{LiClO}_{+}$-based polyurethane) electrolyte/ITO $(30 \Omega / \mathrm{M})$ coated float-glass.
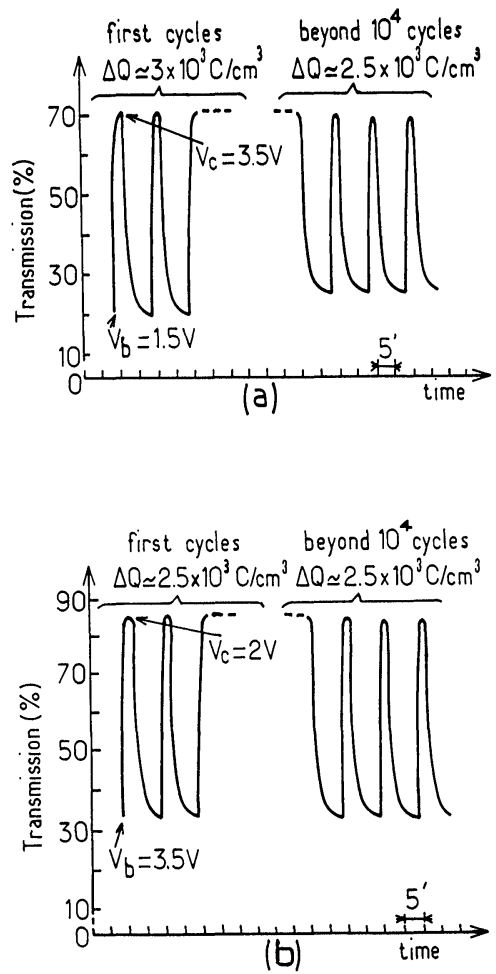

FIGURE 2 Transmission $(\lambda=550 \mathrm{~nm})$ vs time, for repeated coloring and bleaching cycles, of the $\operatorname{ECM}\left(\mathrm{Li}^{-}\right)$.

(a) $\mathrm{Li}_{2-x}^{+} \mathrm{Ni}_{1-x}^{\mathrm{II}} \mathrm{Ni}_{x}^{\mathrm{III}} \mathrm{O}_{2}^{2-}$

(b) $\mathrm{Li}_{x}^{+} \mathrm{W}_{1-x}^{6+} \mathrm{W}_{\mathrm{x}}^{5+} \mathrm{O}_{3}^{2-}$ 


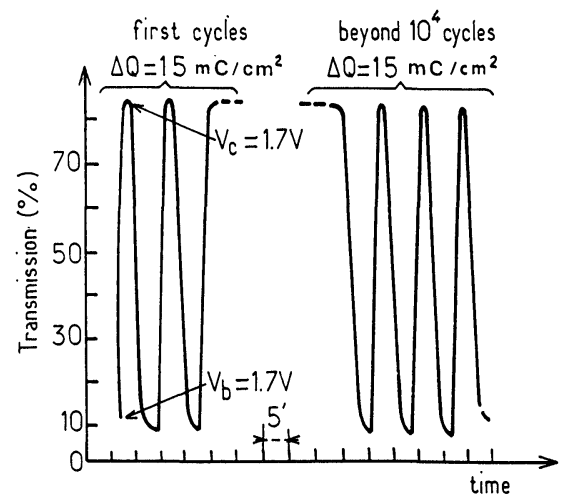

FIGURE 3 Transmissions $(\lambda=550 \mathrm{~nm})$ vs time, for repeated colouring and bleaching cycles, of the ECD: $\mathrm{Li}_{\mathrm{x}} \mathrm{WO}_{3} / \mathrm{SPE}\left(\mathrm{Li}^{+}\right) / \mathrm{Li}_{2-\mathrm{x}} \mathrm{NiO}_{2}$.

\section{ELECTROCHROMIC EVALUATION OF THE ECD}

Figure 3 presents evidence of the expected repetitive-cycling behavior, associated with a net electrochromic effect, of the polymeric solid state ECD. The electrochemi-chromic effect involves the passage of lithium from one electrode to the other, depicted by the reaction:

$$
\begin{aligned}
& \mathrm{Li}_{2}^{+} \mathrm{Ni}^{\mathrm{II}} \mathrm{O}_{2}^{2-}+\mathrm{W}^{6+} \mathrm{O}_{3}^{2-} \stackrel{\text { xLi+ exch. }}{\rightleftharpoons} \mathrm{Li}_{2-x}^{+} \mathrm{Ni}_{1-x}^{\mathrm{II}} \mathrm{Ni}_{\mathrm{x}}^{\mathrm{III}} \mathrm{O}_{2}^{2-}+\mathrm{Li}_{\mathrm{x}}^{-} \mathrm{W}_{1-\mathrm{x}}^{6-} \mathrm{W}_{\mathrm{x}}^{5+} \mathrm{O}_{3}^{2-} \\
& \text { clear }\left(\mathrm{Ni}^{\mathrm{II}}\right) \quad \text { clear }\left(\mathrm{W}^{6-}\right) \quad \text { brown }\left(\mathrm{Ni}^{\mathrm{III}}\right) \quad \text { blue }\left(\mathrm{W}^{5-}\right)
\end{aligned}
$$

\section{CONCLUSION}

We have shown that the texture of the new $\mathrm{ECM}_{2}\left(\mathrm{Li}^{+}\right)$presented here provides fast-reversible electrochemical insertion of lithium.

Two reasons accounting for this process, and which are presently explored (14), can be postulated. Indeed the film texture, which consists of microcrystallites with an average grain size of $50 \AA$ (13), would provide: (i) a random network of channels sufficiently large to permit easy access of $\mathrm{Li}^{+}$ionic species into the bulk of the film; (ii) vacant sites (dangling bonds), at the surface of the crystallites, which themselves supply the ionic species with temporary bonding sites. We have recently described such a phenomena for "similarly amorphous" strontium-titanium oxide films (15, 16).

Finally we are inclined to conclude that by configurations similar to [1], new and efficient "smart windows" may be developed.

\section{REFERENCES}

1. S. Morisaki, K. Kawakami and N. Baba, Jpn. J. Appl. Phys., 27, 314 (1988) and references therein. 
2. M.F. Daniel, B. Desbat, J.C. Lassegues and R. Garie, J. Solid State Chem., 73, 127 (1988).

3. M. Ottariani, S. Panero, S. Morzilli, B. Serosati and M. Lazzari, Solid State Ionics, 20, 197 (1986).

4. S. Hackwood, A.H. Daymen and G. Beni., Phys. Rev. B, 26, 471 (1982).

5. M. Fantini and A. Gorenstein, Solar En. Mat., 16, 487 (1987).

6. P. Delichère, S. Joiret, A. Hugot le Goff, K. Bange and B. Hetz, J. Electrochem. Soc., 135, 1856 (1989).

7. S. Passeri, B. Scrosati, A. Gorenstein, A.M. Anderson and G.C. Grangrist, Proc. Electrochem. Soc., 90-2 (Proc Symp. Electrochromic Mat., 1990), 237 (1990).

8. S. Passerani, B. Scrosati, A. Gorenstein, J. Electrochem Soc., 137, 3297 (1990).

9. B. Buffat,F. Lerbet, F. Defendini and C. Padoy, $n^{\circ} 2639441$. Imprimerie Nationale, 27 rue de la Convention, 75732 Paris cedex 15 (1988).

10. J.P. Couput, G. Campet, B. Morel, J.M. Chabagno, D. Ferry, M. Bourrel, R. Garie, C. Delmas, C. Geoffroy, J. Portier, J. Salardenne, R. Dirkx, United State Patent Application, ref: MNTC010, Finnegan, Henderson, Farabow, Garret \& Dunner, Washington (1989).

11. J.P. Couput, G. Campet, B. Morel, J.M. Chabagno, D. Ferry, M. Bourrel, R. Garie, C. Delmas, C. Geoffroy, J. Portier, J. Salardenne, R. Dirkx, United State Patent Application, ref: ATOC004-PCT, Finnegan, Henderson, Farabow, Garret \& Dunner, Washington (1990).

12. G. Campet, B. Morel, M. Bourrel, J.M. Chabagno, D. Ferry, R. Garie, C. Quet, C. Geoffroy, J. Portier, C. Delmas and J. Salardenne, Materials Science and Engineering B (submitted).

13. B. Morel, G. Campet, B. Darrier, F. Veil and J. Portier (in preparation).

14. B. Morel, G. Campet, J. Salardenne, J. Portier, M. Bourrel, J.M. Chabagno and D. Ferry (in preparation).

15. Z.W. Sun and G. Campet, Materials Science and Engineering B5, 455 (1990).

16. G. Campet, C. Geoffroy, J. Portier, Z.W. Sun and J. Salardenne, Materials Science and Engineering B, (submitted). 

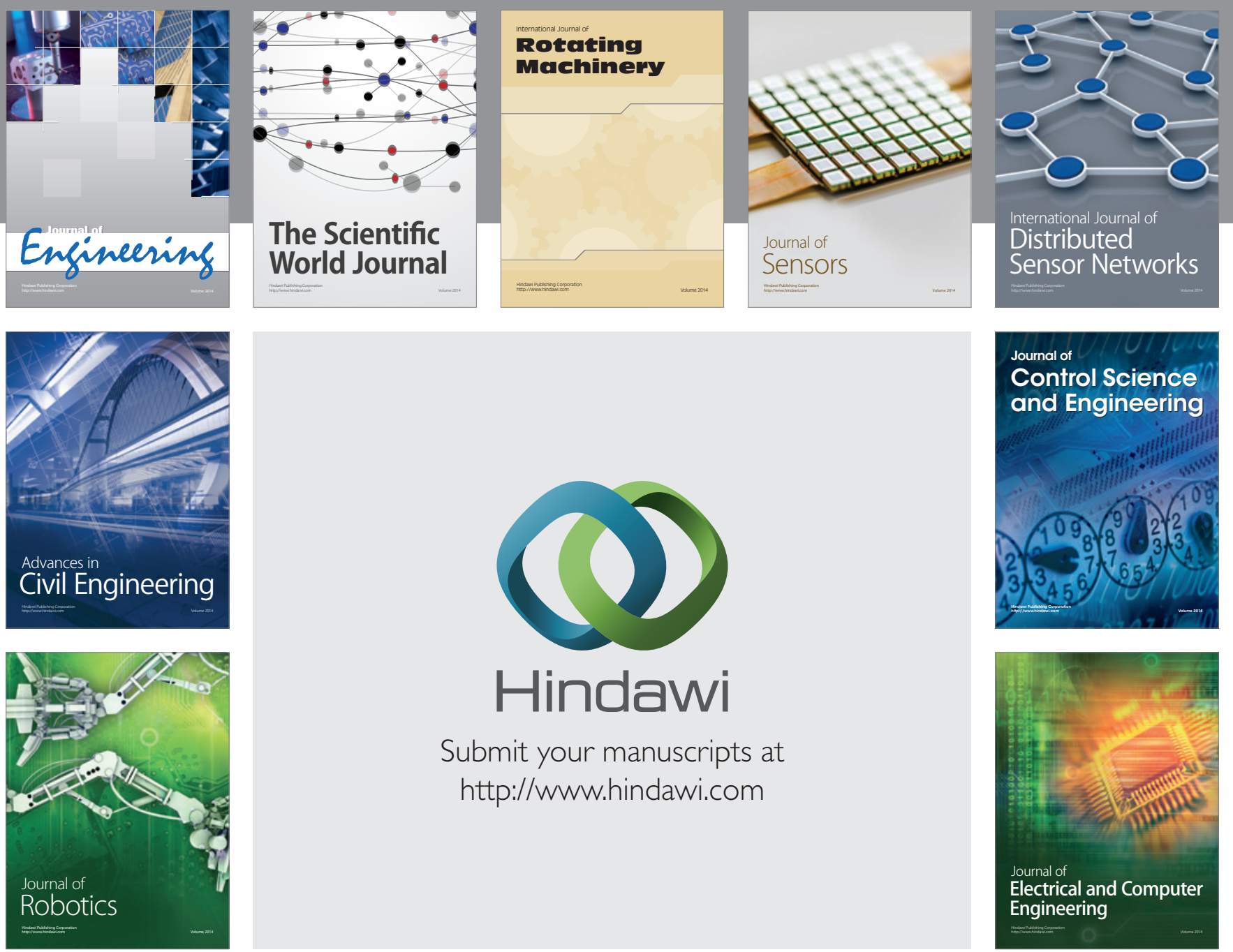

Submit your manuscripts at

http://www.hindawi.com
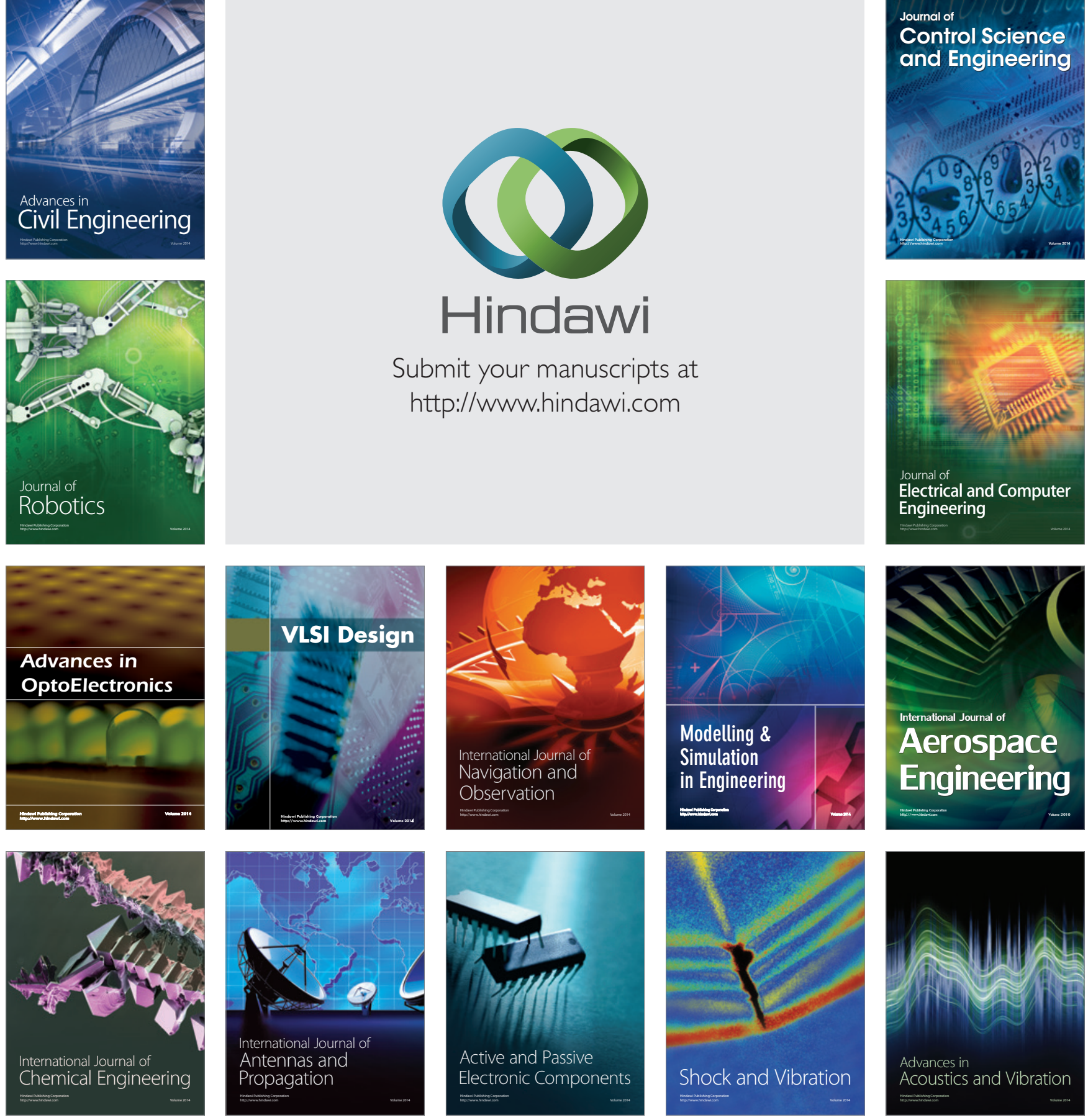